\title{
Role of Plant Growth Regulators in Vegetable Production: A Review
}

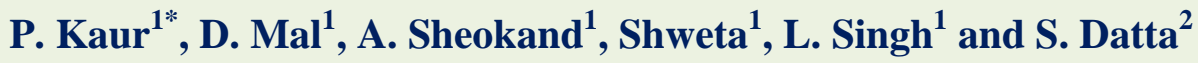 \\ ${ }^{1}$ Lovely Professional University, School of Agriculture, Punjab, India \\ ${ }^{2}$ Uttar Banga Krishi Viswavidyalaya, School of Agriculture, West Bengal, India \\ *Corresponding author
}

\section{A B S T R A C T}

\begin{tabular}{|l|}
\hline Ke y w or d s \\
$\begin{array}{l}\text { Plant growth regulators, } \\
\text { Vegetable production }\end{array}$ \\
\hline Article Info \\
\hline $\begin{array}{l}\text { Accepted: } \\
20 \text { May } 2018 \\
\text { Available Online: } \\
\text { 10 June } 2018\end{array}$ \\
\hline
\end{tabular}

Introduction

The word plant hormones are also known as Phytohormones. These hormones helps to regulate growth of the plant and these hormones are small molecules that derived from different essential metabolic pathways. Thimann in 1948 was coined the term 'Phytohormone' as organic substance that produce naturally in plants.

The 'Plant Hormones' are natural and 'Plant Growth Regulators' are synthetic in nature. They play an important role to growth of plant (P. Hazra and M.G. Som, 2006). There are five types of plant growth regulators such as auxins, gibberellins, cytokinins, abscisic acid and ethylene. The classes are discussed in following table 1

\section{Auxin}

Charles Darwing was the first who proposed the existence of auxin in 1880. It was the first class growth regulator that was discovered. Auxins are those compounds that give positive effect on formation of bud, enlargement of cell and root initiation and they are also helpful for the formation of other growth hormones. IAA is natural occurring hormone while NAA, IBA, 2-4D etc. are synthetic in nature.

\section{Gibberellin}

Kurosava was the Japanese scientist who discovered gibberellins in 1926. It is the second growth regulator. It was extracted from the fungus 'Gibberellafujikuroi' which is the causal organism of "foolish seedling of rice". 
GA stimulate germination of seed and maturation of flower and fruit.

\section{Cytokinins}

Skoog in 1995 experimented that when pith tissues of 'Nicotianatabaccum' were separated from the vascular tissues they grew without division of cell. There are so many different synthetic cytokinins such as 6-benzylamino purine (BAP), kinetin, 6-(benzyl-amino)-9-(2tetrahydropyranyl)-9H-purine (PBA), 1,3diphenylurea, thidiazuron (TDZ), etc.

\section{Ethylene}

This hormone is a gaseous plant hormone which is synthesized from methionine and it is synthesized in all organs of plant.

\section{Abscisic acid}

It is also called plant stress hormone. It act as inhibitory chemical compound that gives direct effect on growth of bud, seed and dormancy of bud. It has inhibitory effect and occurs naturally in plants. It inhibit mRNA and synthesis of protein.

\section{Application of plant growth regulators in vegetable production}

\section{Tomato}

Role of plant growth regulators are beneficial for growth parameters and yield of tomato. The different concentrations of NAA at 25, 50, 75 and 100 ppm and $\mathrm{GA}_{3}$ 20, 40, 60 and $80 \mathrm{ppm}$ were sprayed on the plants of tomato and it was reported that maximum plant height i.e. $85.3 \mathrm{~cm}$ and $82.3 \mathrm{~cm}$ was observed by using NAA at $100 \mathrm{ppm}$ and $\mathrm{GA}_{3}$ at $80 \mathrm{ppm}$ and yield was also increased $483.6 \mathrm{q} / \mathrm{ha}$ and $472.2 \mathrm{q} / \mathrm{ha}$ with the use of NAA at $100 \mathrm{ppm}$ and $\mathrm{GA}_{3}$ at 80 ppm (Prasad et al., 2013).GA @ 125 ppm gave maximum plant height, number of leaves, number of branches per plant, number of fruits, number of flowers, fruit clusters, diameter of fruit, yield per plant $(\mathrm{kg})$ and per plot $(\mathrm{kg})$ and yield per hectare (tonnes) were found to be maximum (Akand et al., 2015). In BARI Hybrid Tomato-8, 4CPA (4- Chlorophenoxy acetic acid) $+\mathrm{GA}_{3}$ applied together after 75 days of transplanting and observed that the tallest plant $(79.35 \mathrm{~cm})$, number of flowers (38.11) and fruits and (19.04) per plant, height $(87.90 \mathrm{~cm})$, number of flowers (49.04) and fruits (21.9) per plant, individual fruit weight $(61.16 \mathrm{~g})$, and fruit yield (27.28 tha $\left.{ }^{-1}\right)$ individual weight (58.44 g) and fruit yield $\left(22.75 \mathrm{t} \mathrm{ha}^{-1}\right)$ were found to be maximum (Rahman et al., 2015). The application of CCC (Cycocel) @ 500 ppm gave increased in height of plant, number of fruits per plant, fruit diameter and per plant seed yield after 45 days of transplanting of tomato seedlings as compared to NAA @ 50 ppm and GA $@ 50$ ppm (Chauhan et al., 2017).

\section{Chilli and capsicum}

The treatments 2,4-D@ 2 ppm, triacontanol @ 5 ppm, NAA 40 ppm and GA $@ 10$ ppm produced $28.75 \%, 25.70 \%, 13.61 \%$ and $2.30 \%$ maximum fruit yield over control. It was recorded that maximum net profit and $\mathrm{B}$ : $\mathrm{C}$ ratio was found in case of $2 \mathrm{ppm} 2,4-\mathrm{D}$. The use of $\mathrm{GA}_{3}$ as foliar spray was not economical (Chaudhary et al., 2006). Maximum seed yield per plant $(8.30 \mathrm{~g})$, seed yield per fruit $(0.35 \mathrm{~g})$, per plant average fresh weight of fruits $(39 \mathrm{~g})$ and per plant average dry weight of fruits $(19.67 \mathrm{~g})$ were obtained by spraying of NAA @ 40ppm as against control (Patel et al., 2016). In capsicum, NAA @ 60 ppm gave maximum plant height $(120.59 \mathrm{~cm})$, number of branches (16.05), days to first flowering (32.51), per plant number of flowers (11.83), weight of fruit $(169.66 \mathrm{~g})$, per plant number of fruits (9.87), per fruit number of seeds (110.78), per plant yield (1.67kg) and per plot 
yield of fruit $(15.07 \mathrm{~kg})$, yield per hectare (69.76t) were recorded (Singh et al., 2017). Different concentrations of growth regulators such as NAA (25, 50 and $75 \mathrm{ppm}), \mathrm{GA}_{3}$ (20, 40 and $60 \mathrm{ppm}), 2,4-\mathrm{D}$ (5, 7.5 and $10 \mathrm{ppm})$ and ethrel (300, 400 and $500 \mathrm{ppm})$ were used in chilli and applied after 30 and 60 days after transplanting. It was recorded that NAA @ 75 ppm gave maximum yield per plant (182.31g) and yield per hectare $(6.37 \mathrm{t})$. On the other hand, $\mathrm{GA}_{3} @ 20$ and 60 ppm treated plants gave maximum plant height $(60.67 \mathrm{~cm})$, maximum dry weight of 20 fruit $(9.39 \mathrm{~g})$. The plant spread in $(\mathrm{N}-\mathrm{S})(36.97 \mathrm{~cm})$ and maximum number of seeds per fruit (60.47) were recorded in 2,4-D @ 7.5 ppm treated plants (Raj et al., 2016).

\section{Brinjal}

Moniruzzaman et al., (2014) used different growth regulators such as $\mathrm{GA}_{3}(30,40$ and 50 ppm) and NAA (20, 40 and 60 ppm) and two varieties such as BARI Begun-5 and BARI Begun -10. It was reported that highest percentage of long and medium styled flower, leaf photosynthesis, number of fruits per plant and fruit yield $(45.50 \mathrm{t} / \mathrm{ha})$ was reported by application of NAA @ 40 ppm. The variety BARI Begun-5 took 40 days for flowering after transplanting which was earlier to $100 \%$ flowering of BARI Begun-10. Application of NAA @ 40 ppm coupled with BARI Begun-5 gave the maximum long-styled flower percent, number of fruits/plant, and the highest fruit yield (49.73 t/ha). Netam and Sharma (2014) studied that $\mathrm{GA}_{3} @ 10$ ppm and NAA @ 20 ppm gave maximum number of branches, number of fruits, fresh fruit weight, total soluble solid. Dhakar and Singh (2015) observes that $\mathrm{GA}_{3} @ 150$ ppm gave heighest plant height, per plant number of leaves, length of leaf, per plant number of branches and stem diameter as compared to $\mathrm{GA}_{3} @ 100$ ppm and 200 ppm and minimum recorded in control.

\section{Cauliflower}

The performance of $\mathrm{GA}_{3}$ and NAA at different levels as dipping of roots and by foliar spray on "SNOWBALL- 16" variety of Cauliflower. It was reported that foliar spray of $\mathrm{GA}_{3}$ at 50 $\mathrm{mg} / \mathrm{l}$ in cauliflower gave better results for diameter of curd $(17.78 \mathrm{~cm})$, length of stalk $(5.22 \mathrm{~cm})$, net weight of curd $(3.53 \mathrm{~kg} / \mathrm{plant})$, curd yield $(12.5 \mathrm{~kg} / \mathrm{plot})$ and required minimum days to $50 \%$ marketable curd (88.80 days) was reported by Sitapara et al., (2011). Highest plant height $(63.10 \mathrm{~cm})$, number of leaves per plant (23.66), leaf length $(59.05 \mathrm{~cm})$, leaf breadth $(18.98 \mathrm{~cm})$ at the time of harvest, diameter of curd $(22.39 \mathrm{~cm})$, marketable yield per hectare $(29.88 \mathrm{t} / \mathrm{ha})$ were recorded by using IAA $10 \mathrm{ppm}+\mathrm{GA}_{3} 70 \mathrm{ppm}$ than control. Also studied that the highest plant height $(65.96 \mathrm{~cm})$, number of leaves per plant (26.42), leaf length $(63.64 \mathrm{~cm})$, leaf breadth $(20.92 \mathrm{~cm})$ at the time of harvest, curd diameter $(25.75 \mathrm{~cm})$, marketable yield per hectare (31.03 t ha-1) were recorded from planting on 15 November and IAA $10 \mathrm{ppm}$ with $\mathrm{GA}_{3} 70$ ppm (Rahman et al., 2016). Jadon et al., 2009 used different doss of NAA@100,120 and 140 ppm. They revealed that higher dose of NAA @ 140 ppm gave higher plant height $(33.83 \mathrm{~cm})$, diameter of the stem $(1.65 \mathrm{~cm})$, spread of the plant $(45 \mathrm{~cm})$ and number of leaves per plants (22.10). Yield attributing characters viz., diameter of curd $(15.10 \mathrm{~cm})$, weight of curd per plant $(0.61 \mathrm{~kg})$, weight of the head per plant $(0.60 \mathrm{~kg})$, length of head per plant $(21.58 \mathrm{~cm})$, yield $(155 \mathrm{q} / \mathrm{ha})$ and dry weight of curd per $100 \mathrm{~g}$ of fresh weight (10.40) were also increased than control.

\section{Cabbage}

Islam et al., 2017 used different concentrations of $\mathrm{GA}_{3}$ on cabbage. They took four different levels of $\mathrm{GA}_{3}$ such as $0,90,120$ and $150 \mathrm{ppm}$. 
Table.1 Plant Growth Regulators and their classes

Plant growth regulators

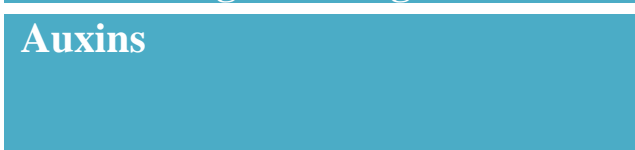

Gibberellins

Cytokinin

Ethylene

Abscisic acid

Jatindersingh (2014)

\section{Classes}

Indole-3-acetic acid (IAA), 1-Naphthaleneacetic acid (NAA), Indole-3-butyric acid (IBA), 2,4-Dichlorophenoxyacetic acid (2-4D), 4-Chlorophenoxyacetic acid (4-CPA).

Gibberellic acid $\left(\mathrm{GA}_{3}\right)$

Kinetin, Zeatin

Ethereal

Dormins, Phaseic Acid

Table.2 Various Plant Growth Regulators and their Functions

\section{Name of the
plant growth
regulators}

Auxin

Gibberellin

Cytokinins

Ethylene

Abscisic acid

\section{Functions}

(a) Apical dominance (b) Cell division and enlargement (c) Shoot and root growth (d) Plant growth movement (e) Parthenocarpy (d) Abscission

(a) Prevent genetical dwarfism (b) Regulation in bolting and flowering (c) Production of parthenocarpic fruit (d) Germination.

(a) Cell and organ enlargement (b) Seed germination (c) Development of bud and shoot growth

(a) Ripening of fruit (b) Seedling growth and emergence (c) Abscission of leaf.

(a) Abscission (b) Dormancy (c) Inhibit seed development and germination of seed (d) Stomatal closing (e) Helps during water stress

Jatindersingh (2014) and P. Hazra and M.G. Som, (2006).

They reported that $\mathrm{GA}_{3}$ at $120 \mathrm{ppm}$ gave highest marketable yield (65.5 t/ha) while minimum yield was recorded in GA 0 ppm (41.2 t/ha). Heighest plant height, maximum number of loose leaves per plant and diameter of head was recorded by using $\mathrm{GA}_{3}$ at 120 ppm while minimum in GA 0 ppm. On the other hand, minimum days were recorded for formation of head in GA $120 \mathrm{ppm}$ and maximum days was recorded in GA 0 ppm. So, they found that $\mathrm{GA}_{3}$ at $120 \mathrm{ppm}$ was more effective. Chaurasiy et al., (2014) used different concentrations of NAA $(40,80$ and $120 \mathrm{ppm})$ and $\mathrm{GA}_{3}(30,60$ and $90 \mathrm{ppm})$ and applied as foliar spray on plants of cabbage at 30 and 45 days after transplanting. They reported that NAA $80 \mathrm{ppm}$ and $\mathrm{GA}_{3} 60 \mathrm{ppm}$ gave heighest plant height, number of leaves per plant, plant spreading, diameter of stem, weight of plant, weight of head, and head yield as compared to all the other treatments and control.

\section{Okra}

Dhage et al., 2011 revealed that IAA @ 100 ppm gave maximum plant height (107.74 $\mathrm{cm})$, intermodal length $(3.1 \mathrm{~cm})$. However, by the application of $\mathrm{GA}_{3} @ 150 \mathrm{ppm}$, minimum days are required for first flowering (39.67 days) and minimum days were required for first harvesting (44.67 days). Ravat et al., 
2015 recorded thatGA 30 ppm gave best seed quality characters like average pod weight $(\mathrm{g}), 100$ seed weight $(\mathrm{g})$. While $\mathrm{GA}_{3}$ gave maximum plant height, number of leaves, per plant number of nodes and thiourea@500 ppm gave maximum no. of pods per plant, length of pod $(\mathrm{cm})$, number of seed per pod, per plant seed yield $(\mathrm{g})$ and seed yield per hectare(q).

\section{Onion and garlic}

Patel et al., 2010 recorded that root dipping treatment of NAA@ 100 ppm significantly reduced physiological loss of weight, reduced loss in spoilage. Anbukkarasi et al., 2013 recorded that CCC, ethylene and and fungicides play an important role in delay in sprouting and extant shelf life in onion. Bannu Priya et al., 2014 reviewed the work done onpre and post-harvest treatments in onion to extend shelf life.

\section{Cucurbits}

Hidayatullah et al., 2012 revealed that $\mathrm{GA}_{3}$ @ $30 \mathrm{ppm}$ increased in production of pistillate flowers, maximum no. of fruits and fruit weight as compared to control in bottle gourd. Dalai et al., 2015 reported that $\mathrm{GA}_{3}$ @20 ppm + NAA @ 100 ppm gave heighest wine length/plant $(\mathrm{cm})$, no. of leaves/ plant. On the other hand, GA 3 @20 ppm+NAA@100 ppm gave maximum yield in cucumber. Sandra et al., 2015 resulted that NAA @ 200 ppm, GA 350 ppm and etheral @50 ppm were very effective for enhancement in vegetative growth, fruit and seed yield and modification in sex expressions and $\mathrm{GA}_{3} @$ $50 \mathrm{ppm}$ was effective in production of hybrid seed in bitter gourd.

\section{Potato}

Foliar application of ethrel at $250 \mathrm{ppm}$ was effective in changing phenotype of plant, increased in plant height, diameter of shoot, per plant number of tubers and total yield of tuber as compared to control (Awati et al., 2016). Application of $\mathrm{GA}_{3}$ at 60 days after transplanting had increased in height of plant but number of tubers, weight and content of dry matter were not affected. Late application of $\mathrm{GA}_{3}$ leads for induction of high percentage of sprouted tubers prior to harvest and also lead to increase physiological age of tubers (Alexios et al., 2006).

\section{Pea}

Singh et al., 2016 reported that $\mathrm{GA}_{3}$ at 200 ppm gave significantly increased in height of plant, number of leaves, total number of branches, number of pods, length of pod and 100 seed weight.

From this review it has been concluded that PGRS regulate physiological process to the crop plants like rooting, flowering, growth, sprouting, ripening and use of PGRS in vegetable production found to be beneficial for yield and yield contributing characters of various vegetable crops.

\section{References}

Akand, M. H., Mazed, H. K., Islam, M. A., Pulok, M., and Moonmoon, S. N. C. J. F. (2015). Growth and yield of tomato (Lycopersicon esculentum Mill.) as influenced by different level of gibberellic acid application. International Journal of Applied Research, 1(3), 71-74.

Alexopoulos, A. A., Akoumianakis, K. A., and Passam, H. C. (2006). Effect of plant growth regulators on the tuberisation and physiological age of potato (Solanum tuberosum L.) tubers grown from true potato seed. Canadian journal of plant science, 86(4), 12171225. 
Anbukkarasi, V., Paramaguru, P., Pugalendhi, L., Ragupathi, N. and Jeyakumar, P. 2013. Studies on pre and post-harvest treatments for extanding shelf life in onion-A review. Agri. Review, 34(4):256-268.

Bannu Priya, E.P., Sinja, V.R., Alice, R.P.J.S., Shanmugasundaram, S. and Alagusundaram, K. 2014. Storage of onions- A review. Agri. Reviews, 35(4): 239-249.

Chauasiy, J., Meena, M., Singh, H., Adarsh, A., and Mishra, P. K. (2014). Effect of $\mathrm{GA}_{3}$ and NAA on the Growth and Yield of Cabbage (Brassicaoleracea Var. Capitata L.) cv. Pride of India. The Bioscan, 9(3), 1139-1141.

Chaudhary, B. R., Sharma, M. D., Shakya, S. M., and Gautam, D. M. (2006). Effect of plant growth regulators on growth, yield and quality of Chilli (Capsicum annuum L.) at Rampur, Chitwan. Journal of the Institute of Agriculture and Animal Science, 27, 6568.

Chauhan S. A., Patel N.B., Mehta D.R., Patel J.B., ZalaIshita M. And Vaja A.D. (2017). Effect of Plant Growth Regulators on Seed Yield and Its Parameters of Tomato (Lycopersicon esculentumL). International Journal of Agriculture Sciences, 9(8), 3906-3909.

Dalai, S., Singh, M. K., Singh, K. V., Kumar, M., Malik, S., and Kumar, V. (2015). Effect of Foliar Application of $\mathrm{GA}_{3}$ and NAA on Growth, Flower-Ing Yield and Yield Attributes of Cucumber [Cucumis sativus L.]. Annals of Horticulture, 8(2), 181-194.

Dhage, A. A., Nagre, P. K., Bhangre, K. K., and Pappu, A. K. (2011). Effect of plant growth regulators on growth and yield parameters of okra. Asian Journal of Horticulture, 6(1), 170-172.

Dhakar, S. and Singh, Y. (2015). Studies on the effect of inorganic fertilizers and plant growth regulator on growth and yield of brinjal (Solanum melongena L.) The Indian J.Basic Appl. Res., 1(2): 2739.

Hazra, P., and M.G. Som. 2015. Vegetables science. 109-113.

Hidayatullah, T. M., Farooq, M., Khokhar, M. A., and Hussain, S. I. (2012). Plant growth regulators affecting sex expression of bottle gourd (Lagenariasiceraria molina) plants. Pakistan J. Agric. Res. Vol, 25(1).

Islam, M. M., Khan, M. S. I., and Parven, A. (2017). Growth and Yield Potential of Late Planting Cabbage Influenced by Gibberellic Acid. International Journal of Business Social Science Research, 6(1): 62-67.

Jadon, R. S., Lekhi, R., Sharma, S., and SharmaR 2009. Effect of Gibberelic acid, IBA and NAA as Foliar Spray on the Growth, Yield and Quality of Cauliflower (Brassica oleracea var. botrytis L.). Agriculture: Towards a New Paradigm of Sustainability, 230.

Moniruzzamani, M.; Khatoon, R.; Hossain, M. F. B.; Jamil, M. K. and Islam, M. N. (2014). Effect of $\mathrm{GA}_{3}$ and NAA on physio-morphological characters, yield and yield componenets of brinjal (Solanum melongena L.). Bangladesh J. Agril. Res., 39(3): 397- 405.

Netam, J. L. and Sharma, Richa. (2014). Efficacy of plant growth regulators on growth characters and yield attributes in brinjal (Solanum melongena L.) cv. Brinjal 3112. IOSR J.Agric. Vet. Sci., (IOSR-JAVS), 7: 27-30.

Patel, M.J., Patel, H.C. and Chavda, J.C. 2010. Influence of plant growth regulators and their application methods on yield and quality of onion (Allium cepa L.). Asian journal of horticulture, 5(2): 263-265. 
Patel, V. P., Lal, E. P., and John, S. A. (2016). Comparative study of the effect of plant growth regulators on growth, yield and physiological attributes of Chilli, Capsicum annuum $\mathrm{L}$ cv. KashiAnmol. International Journal of Farm Sciences, 6(1), 199-204.

Prasad, R. N., Singh, S. K., Yadava, R. B., and Chaurasia, S. N. S. (2013). Effect of $\mathrm{GA}_{3}$ and NAA on growth and yield of tomato. Vegetable Science, 40(2), 195197.

Rahman, M. A., Imran, M., Ikrum, M., Rahman, M. H., and Rabbani, M. G. (2016). Effects of Planting Date and Growth Hormone on Growth and Yield of Cauliflower. Journal of Environmental Science and Natural Resources, 9(2), 143-150.

Rahman, M., Nahar, M. A., Sahariar, M. S., and Karim, M. R. (2015). Plant growth regulators promote growth and yield of summer tomato (Lycopersicon esculentum Mill.). Progressive Agriculture, 26(1), 32-37.

Raj, A. C., Holebasappa, K., Hore, J. K., and Das, S. (2016). Effect of plant growth regulators on growth and yield of Chilli (Capsicum annuum L.). Research on Crops, 17(2).

Ravat, A. K., and Nirav, M. (2015). Influence of plant growth regulators on growth, seed yield and seed quality in okra [Abelmoschus esculentus (L.) Moench] cv. GAO-5 under middle Gujarat condition. International Journal of Agricultural Sciences, 11(1), 151-157.

Ravindra, A., Anjanabha, B., and Bharat, C. (2016). Effect of foliar application of plant growth regulators on growth and yield of potato seed tubers propagated from micro plantlets on soilless solid media in greenhouse. Advance Research Journal of Crop Improvement,7(2), 234-239.

Sandra, N., kumarLal, S., Chakrabarty, S. K., and Talukdar, A. (2015). Effect of plant growth regulators on sex expression, fruit setting, seed yield and quality in the parental lines for hybrid seed production in bitter gourd (Momordicacharantia). Indian Journal of Agricultural Sciences, 85(9), 118591.

Singh, J. (2014). Fundamentals of Horticulture. Kalyani Publishers, New Delhi, India. pp. 162-174.

Singh, M., John, S. A., Rout, S., and Patra, S. S. (2016). Effect of $\mathrm{GA}_{3}$ and NAA on growth and quality of garden Pea (Pisum sativum L.) cv. Arkel. The Bioscan, 10(3), 381-383.

Singh, P., Singh, D., Jaiswal, D. K., Singh, D. K., and Singh, V. (2017). Impact of Naphthalene Acetic Acid and Gibberellic Acid on Growth and Yield of Capsicum, Capsicum annum (L.) cv. Indra under Shade Net Conditions. International Journal of Current Microbioloy and Applied Science, 6(6), 2457-2462.

Sitapara, H. H., Vihol, N. J., Patel, M. J., and Patel, J. S. (2011). Effect of growth regulators and micro nutrient on growth and yield of cauliflower cv.'Snowball16'. Asian Journal of Horticulture. 6(2), 348-351.

\section{How to cite this article:}

Kaur P., D. Mal, A. Sheokand, Shweta, L. Singh and Datta S. 2018. Role of Plant Growth Regulators in Vegetable Production: A Review. Int.J.Curr.Microbiol.App.Sci. 7(06): 21772183. doi: https://doi.org/10.20546/ijcmas.2018.706.258 